\title{
Flere blodtrykksmålinger må til
}

\author{
Blodtrykket må måles flere ganger før man starter behandling eller \\ endrer den.
}

Blodtrykksmålinger kan være usikre. Hvor usikre? I en randomisert studie med 444 hypertonipasienter, de fleste menn i 60-årene, ble blodtrykket målt flere ganger gjennom en periode på 18 måneder på tre ulike måter: under alle ordinære polikliniske konsultasjoner (7 121 målinger), av pasientene selv

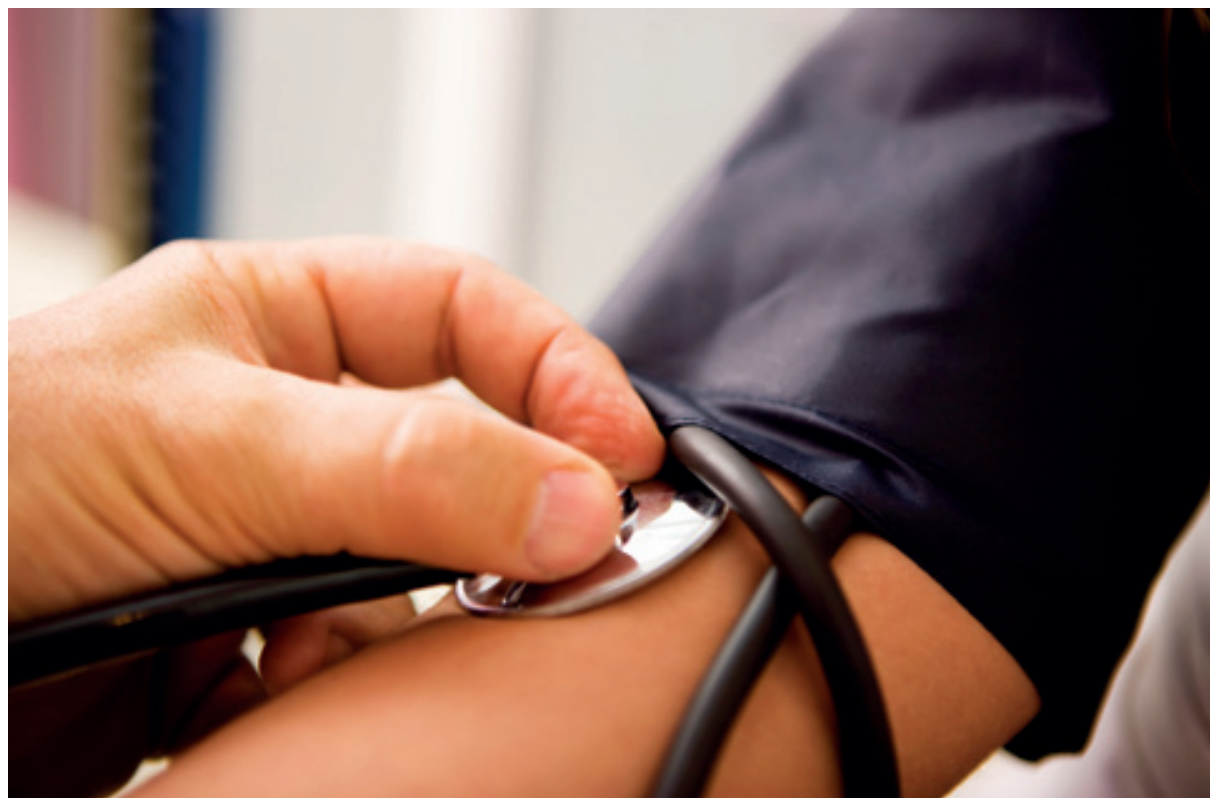

Illustrasjonsfoto Istockphoto

\section{$\emptyset k t$ inflammasjon ved hyperparatyreoidisme}

\section{Primær hyperparatyreoidisme \\ kan påvirke uttrykket av inflamma- \\ toriske og metabolske gener \\ i fettvevet.}

Primær hyperparatyreoidisme er en av de vanligste endokrine sykdommene. Tilstanden rammer $1-2 \%$ av befolkningen, og det er høyest prevalens hos kvinner etter overgangsalderen. Den hyppigste årsaken er overproduksjon av parathyreoideahormon fra et adenom i en av de fire glandulae thyroidea. Behandlingen er som regel kirurgisk fjerning av adenomet. Tilstanden kan føre til økt frisetting av kalk fra skjelettet, forhøyet serum-kalsium og beinskjørhet. Pasientene har også økt forekomst av diabetes mellitus, høyere kroppsmasseindeks, forhøyet LDLkolesterolnivå og økt risiko for død av hjerte- og karsykdom. Studien utgår fra forskningsgruppen ved Hormonlaboratoriet, hjemme minst tre ganger i uken (100 842 målinger) og med standardiserte målinger av trent sykepleier flere ganger med fem minutters mellomrom hver sjette måned (3 218 målinger).

Det systoliske blodtrykket varierte betydelig ved studiestart. Andelen pasienter som ble bedømt som adekvat behandlet i hver gruppe var henholdsvis $28 \%, 47 \%$ og $68 \%$. Ved senere målinger var målevariasjonen for enkeltpasienter stor. Ingen enkeltmålinger kunne med minst $80 \%$ sikkerhet fastslå om pasienten var adekvat behandlet eller ikke, men sikkerheten økte med flere målinger, mest inntil 5-6 målinger.

- Dette er en stor og grundig studie, sier professor Rune Wiseth ved Klinikk for hjertemedisin, St. Olavs hospital. - Den bekrefter det vi lenge har visst, nemlig at det må gjøres flere målinger før man starter opp eller endrer medikamentell blodtrykksbehandling. En enkeltmåling er av liten verdi.

Det er viktig at leger i både primær- og spesialisthelsetjenesten sørger for optimale forhold ved måling av blodtrykk, og at det gjøres flere målinger før det foretas kliniske beslutninger om blodtrykksbehandlingen, sier Wiseth.

\section{Petter Gjersvik}

petjense@online.no

Tidsskriftet

\section{Litteratur}

1. Powers BJ, Olsen MK, Smith VA et al. Measuring blood pressure for decision making and quality reporting: where and how many measures? Ann Intern Med 2011: 154: 781-8.
Haukeland universitetssykehus, og Institutt for indremedisin, Universitetet i Bergen.

Vi har sammenliknet genuttrykket i subkutant fettvev fra halsen til 16 pasienter operert for primær hyperparatyreoidisme og $\mathrm{i}$ fettvev fra 16 pasienter operert for eutyreot struma. Gruppene var matchet i vekt. Pasienter med kjent inflammatorisk sykdom ble ekskludert.

Genuttrykket bedømt ved DNA-mikromatriser viste at 608 gener var ulikt uttrykt i de to gruppene -347 gener var oppregulert og 261 gener nedregulert ved primær hyperparatyreoidisme. Den største gruppen oppregulerte gener tilhørte immunitets- og forsvarsprosesser, de nedregulerte genene tilhørte metabolske prosesser. Blant de mest oppregulerte genene var calgranulinene S100A8 og S100A9, matriks metalloproteinase 9, CD14 og folatreseptor 2. Disse genene øker ved aktivering av monocytter/ makrofager.
Kronisk inflammasjon synes å spille en viktig rolle i utviklingen av både osteoporose, kardiovaskulær sykdom, diabetes mellitus og fedme. Våre funn viser at primær hyperparatyreoidisme er forbundet med endret genuttrykk i fettvev og økt inflammasjon.

\section{Monika H.E. Christensen \\ monika.christensen@med.uib.no \\ Institutt for indremedisin \\ Universitetet i Bergen}

\section{Litteratur}

1. Christensen MH, Dankel SN, Nordbø Y et al. Primary hyperparathyroidism influences the expression of inflammatory and metabolic genes in adipose tissue. PLoS One 2011; 6: e20481. 